\title{
Cavallo, G., Leer en Bizancio, Buenos Aires, Ampersand, 2017, 294 pp. ISBN 9789874161031. Traducido del italiano por Antonio Gabriel Natolo.
}

\author{
Malena Trejo \\ Universidad Nacional de La Plata, Argentina \\ malena.trejo.mt@gmail.com
}

La editorial Ampersand incluye en la serie Scripta Manent, dedicada a la historia social de cultura escrita, la traducción al castellano de Lire à Byzance del prestigioso paleógrafo italiano Guglielmo Cavallo. Estudio publicado originalmente en francés en el año 2006 dentro de la serie Séminaires byzantins de Belles Lettres, es en esta oportunidad introducido por primera vez en las bibliografías en lengua castellana gracias a la traducción de Antonio Gabriel Natolo bajo el sello Ampersand. La presente edición ha sido editada por su autor, quien agrega correcciones y ampliaciones derivadas de las ediciones en griego (Atenas, Ekdoseis Agra, 2008) y en italiano (Milán, Sylvestre Bonnard, 2008), así como también actualiza la bibliografía incorporando títulos relevantes aparecidos en los diez años que median desde su primera edición francesa.

Leer en Bizancio representa una obra fundamental en el marco de la historia de la lectura antigua. La trascendencia de las ideas desarrolladas por Cavallo hablan por sí solas cuando se considera el impacto que el estudio ha tenido en la última década ${ }^{1}$. Tratándose ésta de la primera edición en castellano, nos parece indispensable señalar los hallazgos de la edición así como también la importancia de su inserción en las bibliografías en castellano.

Cavallo sostiene como punto de partida que las prácticas de la lectura de la Antigüedad tardía no difieren de las precedentes ni, por ende, de las realizadas en Bizancio (p. 109). De este modo, tanto la metodología utilizada para abordar la evidencia documental como las conclusiones derivadas de su examen son también aplicables a los períodos previos. Es por esto también que, si bien el foco del estudio es las formas de cultura escrita en Bizancio, Cavallo utiliza con frecuencia testimonios de la Roma Imperial para sustentar su argumentación. Su tesis es en consecuencia también explicativa de estos períodos previos, lo cual es relevante si se tiene en cuenta la escasa documentación disponible acerca de la práctica de la lectura, de la escritura y de su adquisición y desarrollo. Los dos capítulos iniciales de hecho son claramente introductorios: Cavallo reflexiona sobre los problemas empíricos al estudiar la práctica de la lectura en la historia antigua y recupera brevemente el estado de situación en tiempos imperiales. Esta brevedad sin embargo es compensada por la referencia a estudios especializados en cada uno de los puntos que toca superficialmente. De este modo, los capítulos iniciales funcionan como contextualizadores del tema en estudio y al mismo tiempo como introductores al problema de la lectura y escritura en la antigüedad en general. Los capítulos dedicados a Bizancio se detienen en el análisis y contraste de fuentes documentales, sin abandonar por eso tampoco la mención a pie de página de bibliografía crítica especializada sobre cada uno de los aspectos involucrados. Este modo de abordar la bibliografía vuelve al texto ligero y de sencilla lectura, lo cual a su vez lo torna ameno para un lector no especializado.

Paralelamente, Cavallo argumenta que siendo la evidencia documental sumamente escasa, debe recurrirse a fuentes iconográficas para estudiar las formas de circulación de la cultura escrita. Por este motivo, acompaña el desarrollo de sus argumentos con reproducciones de estos testimonios, tanto en blanco y negro en el cuerpo del texto como a color en un cuadernillo especial en papel ilustración. La información de estas imágenes se consigna tanto al pie de cada una de ellas como en un índice de ilustraciones que antecede al tratado, lo cual da cuenta de la prioridad de la evidencia iconográfica por sobre la bibliografía crítica como fuente de información. La bibliografía consignada en un apartado especial es sólo aquella que se agregó para la 
presente edición, motivo por el cual se echa de menos una bibliografía general o de títulos citados. El estudio es acompañado finalmente por un índice analítico de nombres antiguos y bizantinos.

Tras lo expuesto, se puede concluir que Leer en Bizancio constituye no sólo un título fundamental en el marco de los estudios especializados, sino también una herramienta pedagógica de gran valor gracias tanto a la calidad de la edición como al estilo ameno de Cavallo, conservado con fidelidad por el traductor. Su incorporación a las bibliografías en lengua castellana representa una actualización de éstas, haciendo posible el acceso a bibliografía de enorme peso al lector no competente en lengua francesa, lo cual es especialmente relevante si se considera el aspecto divulgativo del estudio.

\section{Notas}

1 Debido a que el estudio cuenta con una década de presencia en el campo de los estudios sobre historia de la lectura, para una reseña pormenorizada del estudio en sí remitimos a Isaac, M.T. (2008) Guglielmo Cavallo, Lire à Byzance, 2006. L'Antiquité Classique, vol.77. pp. 559-561; Wilson, N. G. (2007) Guglielmo Cavallo, Lire à Byzance, Séminaires Byzantins, 1. Paris: Les Belles Lettres, 2006. pp. viii, $165 € 23.00$ (pb.). ISBN 978-2-251-44309-6. Translated from Italian by P. Odorico and A.-P. Segonds. Classical World, vol. 101. No.1. pp. 114-115. 